\title{
Riparian vegetation response to different intensities and seasons of grazing
}

\author{
RICHARD W. LUCAS, TERRELL T. BAKER, M. KARL WOOD, CHRISTOPHER D. ALLISON, AND DAWN M. \\ VANLEEUWEN
}

At the time research was conducted, authors were Graduate Research Assistant, Animal and Range Science Department, New Mexico State University, Las Cruces, N.M. 88003; Assistant Professor and Extension Riparian Management Specialist, New Mexico State University-Cooperative Extension Service, Las Cruces, N.M. 88003; Director, New Mexico Water Resources Research Institute, Las Cruces, N.M. 88003; Professor and Extension Range Management Specialist, New Mexico State University-Cooperative Extension Service, Las Cruces, N.M. 88003; and Associate Professor, Agricultural Biometrics, New Mexico State University, Las Cruces, N.M. 88003.

\begin{abstract}
Sustainable management of riparian ecosystems depends on our understanding of these complex systems. Thus far, the scientific literature has not adequately addressed the effects of livestock grazing on riparian areas in the American southwest. Most available information is observational, anecdotal, based on unreplicated experiments, or compares heavily grazed areas to areas from which livestock have been completely excluded. This study, in the Black Range of western New Mexico, compared effects of different seasons of use (cool season, warm season, and dormant season) and grazing intensities (light, moderate, and none) of cattle on young narrowleaf cottonwood (Populus angustifolia James) populations, and herbaceous vegetation in 2 adjacent southwestern riparian areas. Cottonwoods in lightly grazed and moderately grazed plots received significantly greater use than cottonwoods in ungrazed plots which experienced negligible grazing pressure. Increased grazing pressure did not have significant impacts on cottonwood populations. Effects of season of use were significant on both herbaceous species richness and diversity. We conclude that no single riparian area management approach is best in all situations, but the grazing treatments used in this study appear to have been successful at maintaining riparian communities.
\end{abstract}

Key Words: cottonwood, populus angustifolia, season of use, southwest, New Mexico, cattle

Riparian vegetation is vital for the maintenance of stream and riparian ecosystems (Goodwin et al. 1997, Kovalchik and Elmore 1992, Millar 2000, Murphy and Meehan 1991). Streamside vegetation stabilizes channel banks with root systems, attenuates the erosive force of flood water, and protects banks from debris washed downstream (Skovlin 1984). During high flows, water surges over streambanks onto adjacent vegetated areas. Flexible

The authors wish to thank the Schneberger family, owners and operators of the Rafter Spear Ranch, for use of their cattle and for help facilitating the research; Dr. C. Marlow for useful comments during the planning stages of this research; $B$. Allred, L. Stavast, C. Larsen, B. Mertz, and C. Wood for assistance in the field. Thank you also to two anonymous reviewers who helped to improve the quality of this manuscript.

Manuscript accepted 29 Feb. 04

\section{Resumen}

El manejo sustentable de los ecosistemas ribereños depende de nuestro entendimiento de estos complejos sistemas. La literatura científica actual no ha abordado adecuadamente los efectos del apacentamiento del ganado en las áreas ribereñas del suroeste Americano. La mayoría de la información disponible es observacional, anecdotal, basada en experimentos sin repeticiones 0 compara áreas fuertemente apacentadas con áreas en las que el ganado ha sido excluido completamente. Este estudio, realizado en el Pastizal Black del oeste de Nuevo Mexico, comparó los efectos de diferentes épocas de uso (estación fría, estación caliente y época de dormancia) e intensidades de apacentamiento (ligero, moderado y sin apacentamiento) del ganado en poblaciones juveniles de "Narrowleaf cottonwood" (Populus angustifolia James) y la vegetación herbácea en dos áreas ribereñas adyacentes en suroeste. EI "Cottonwood" en las parecelas apacentadas ligera y moderadamente recibieron un uso significativamente mayor que “Cottonwood"de las parecelas sin apacentamiento, las cuales experimentaron una presión de apacentamiento mínima. Aumentar la presión de apacentamiento no tuvo impactos significativos en las poblaciones de "Cottonwood". Los efectos de la época de uso fueron significativos tanto en la riqueza como la diversidad del estrato herbáceo. Concluimos que ninguna estrategia individual de manejo de áreas ribereñas es la mejor para todas las situaciones, pero los tratamientos de apacentamiento usados en este estudio parecen haber sido exitosos para mantener las comunidades ribereñas.

riparian vegetation such as sedges, willows, and young cottonwoods are bent over by the force of the water current, thus serving as a protective barrier to guard against bank erosion (Kauffman et al. 1996, Meehan and Platts 1978, Platts 1991). Prostrate vegetation also acts to trap sediment as it tends to increase water turbulence and decrease water velocity (Heimann and Roell 2000). As water velocity slows, larger sediment particles settle out of suspension and eventually become part of the bank or floodplain, adding both nutrients and bulk mass (DeBano and Schmidt 1989, Kauffman et al. 1996, Meehan and Platts 1978, Platts 1991). In areas undergoing sediment deposition, repeated deposition events can quickly result in substantial bank and floodplain building. Although there are exceptions (Pearce et al. 1998), herbaceous riparian vegetation growing along a stream- 
bank often captures much of the sediment washing into streams with overland flow (Elmore and Beschta 1987), thereby acting as a natural filter to improve water quality and reduce erosion (Heimann and Roell 2000, Meehan and Platts 1978),

Concern has recently been expressed for the apparent lack of cottonwood regeneration (Bradley and Smith 1986, Busch and Smith 1995, Ellis et al. 1998, Howe and Knopf 1991, Stromberg and Patten 1992) as well as the degradation and alteration of herbaceous riparian species communities (Ellis et al. 1998, Martin and Chambers 2001) in western North America. The loss of riparian vegetation is often attributed to grazing livestock (Armour et al. 1994, Behnke 1979, Belsky and Blumenthal 1997, Belsky et al. 1999, Carothers 1977, Davis 1977, Donahue 1999, Fleischner 1994, Li et al. 1994, Magilligan and McDowell 1997, Meehan 1991), even though many different factors, such as the extirpation of beaver (Baker and Boren 2000, Elmore and Kauffman 1994, Kovalchik and Elmore 1992, Naiman 1988), mining (Scurlock 1998, Todd and Elmore 1997), dam erection (Rood and Heinze-Milne 1989), or road construction (Jones et al. 2000, Weaver and Hagans 1996) have also contributed to their decline (Swanson 1989).

The effects of herbivory on riparian plants is a critical issue because of the importance of vegetation in riparian and stream ecology (Kauffman and Krueger 1984). Undoubtedly, livestock grazing has had an impact on riparian vegetation in the western United States (Baker and Boren 2000 ), but the magnitude of such an impact is largely unknown or poorly quantified (Brown and McDonald 1995, Larsen et al. 1998). The scientific literature on this subject contains a great deal of personal opinion, speculation, and other anecdotal work rather than scientific documentation (Brown and McDonald 1995, Clary 1999, Larsen et al. 1998, Trimble and Mendel 1995). Many studies only include grazing in terms of presence or absence (Clifton 1989, Gunderson 1968, Kauffman et al. 1983a, Magilligan and McDowell 1997, Rhodes et al. 1995, Sidle and Sharma 1996). If the general effects of cattle grazing on riparian vegetation are to be evaluated, the scientific method would require a more robust examination of grazing in order to make more reliable conclusions about the effects of cattle grazing. Rinne (1988, 1999) and Pieper (1994) have both suggested the scientific community and land managers cannot make firm conclusions about the impact of livestock grazing on riparian vegetation because we do not have enough good data upon which to base conclusions.

The objectives of this study were to evaluate the effects of different levels of grazing intensity, during different seasons of use, on cottonwood populations and other herbaceous vegetation in 2 montane riparian areas in western New Mexico.

\section{Methods}

\section{Study Site}

This study was conducted on 2 separate streams on the western slope of the Black Range Mountains in western New Mexico (332 $\left.24^{\prime} 15^{\prime \prime} \mathrm{N}, 108^{\circ} 1^{\prime} 30^{\prime \prime} \mathrm{W}\right)$, about 230 $\mathrm{km}$ northwest of Las Cruces. Seventyfour Draw and Turkey Run are both first order, intermittent, B3 streams (Rosgen 1994) flowing through adjacent watersheds, eventually converging to form Hoyt Creek. Both streams lie within the same grazing allotment and consequently have been, and are subject to, similar anthropogenic factors since at least the 1950's when the current ranching family began their cattle operation. Both watersheds also have similar geomorphology, hydrology, vegetation, mean elevation $(2255 \mathrm{~m})$, and mean annual precipitation $(350 \mathrm{~mm}$ ). A majority of the precipitation occurs as rain in the summer months from July through September. Mean annual summer temperature is $18^{\circ} \mathrm{C}$ and mean annual winter temperature is $-1^{\circ} \mathrm{C}$. Streamflow occurs primarily after rainfall events, predominantly in the late summer and early fall months (July-October), but may persist locally for months afterwards. Substantial snowmelt may also create streamflow. Soils in both watersheds are Cumulic Haploborolls (Souders and Subirge 1984). Using the hydrometer method (Gee and Bauder 1986), soils along the streambank in Seventyfour Draw were found to be primarily sand and loamy sand with clay contents between $1 \%$ and $5 \%$. Soils along the streambank in Turkey Run were found to be primarily loamy sand and sandy loam with clay content between $6 \%$ and $8 \%$.

Dominant vegetation in the riparian corridor of both watersheds consists of ponderosa pine (Pinus ponderosa Laws.), narrowleaf cottonwood (Populus angustifolia James), Arizona alder (Alnus oblongifolia Torr.), and associated understory species which include Kentucky bluegrass ( $\mathrm{Poa}$ pratensis L.), blue grama (Bouteloua gracilis [Kunth] Griffiths), nodding brome (Bromus anomalus Fourn.), Louisiana sage (Artemesia ludoviciana Nutt.), western yarrow (Achillea millefolium L.), cinquefoil (Potentilla hippiana Lehm.), annual muhly (Muhlenburgia ramulosa [Kunth] Swallen), trailing daisy (Erigeron flagellaris Gray), and comenlina (Comenlina dianthifolia Nutt.). Upland vegetation is dominated by ponderosa pine, Gambel's oak (Quercus gambelii Nutt.), alligator juniper (Juniperus deppeana Steudel), pinyon pine (Pinus edulis Engelm.), mountain mahogany (Cercocarpus montanus Raf.), blue grama, and New Mexican muhly (Muhlenbergia pauciflora Buckl.). Cottonwoods do not form a contiguous forest along streams in these 2 watersheds. Instead they exist as clumped stands periodically interspersed along both stream reaches. In an average cottonwood stand in Turkey Run, cottonwood trees we defined as mature (those trees having a diameter at breast height [dbh] greater than $15.5 \mathrm{~cm}$ ) occupy a basal area of $19.2 \mathrm{~m}^{2}$, trees we defined as young (dbh is between 2.5 and $15.5 \mathrm{~cm}$, inclusive) occupy a basal area of $0.03 \mathrm{~m}^{2}$. We defined saplings as those trees having a dbh less than $2.5 \mathrm{~cm}$. Mature ponderosa pines occupy a basal area of $33.3 \mathrm{~m}^{2}$, young ponderosa pines occupy a basal area of $2.4 \mathrm{~m} 2$. In Seventyfour Draw, cottonwoods in the mature and young classes occupy basal areas of 5.6 and $0.7 \mathrm{~m}^{2}$ respectively. Mature and young ponderosa pines occupy 26.5 and $2.1 \mathrm{~m}^{2}$ respectively.

\section{Study Design}

A randomized complete block design with a factorial arrangement of treatments was used to evaluate 3 grazing intensity treatments (none, light, and moderate) and 3 separate seasons of use (dormant, cool, and warm). We defined light grazing as cattle using $20-30 \%$ of available standing biomass (dry mass) and moderate grazing as cattle using $40-50 \%$ of available standing biomass. Grazing seasons corresponded to the phenological stage of cool and warm season grasses. Dormant season grazing was conducted in February and March, cool season grazing was conducted in May and June, and warm season grazing was conducted in August and September.

Treatments were randomly assigned within 2 blocks, each containing seven, 0.4 ha plots (enclosures), at the beginning of the experiment and were not reassigned for the duration of the study. Each stream served as a separate block. One enclosure in each watershed served as the ungrazed control plot for all 3 seasons of use. The remaining 6 plots in each watershed were assigned treatments in a $2 \times 3$ factorial 
treatment structure defined by the factors grazing intensity (light and moderate) and season of use (dormant, cool, and warm). Plots were selected based upon 4 criteria: 1) presence of stream running through the enclosure; 2) similar frequencies of narrow-leaf cottonwood and ponderosa pine within 3 diameter classes; 3) similar basal area of respective tree species; and 4) presence of similar herbaceous species. Baseline pre-treatment data were collected in 1999, one season prior to applying treatments, to give a standard of reference when determining the presence or absence of a treatment effect.

\section{Grazing Intensity}

To apply grazing treatments, enclosures were stocked with 3 to 5 second-year cross-bred heifers. Heifers were allowed to stay in the enclosures until the target grazing intensity levels had been reached. This ranged from 2 to 8 days. The decision to release cattle from the enclosures was based on comparison against 3 protected reference areas $\left(2.3 \mathrm{~m}^{2}\right.$ each $)$ within each plot (Cook and Stubbendieck 1986). Reference areas were protected with welded wire-panel cages as described below.

Grazing intensity was estimated using the cage comparison method (Cook and Stubbendieck 1986, Pieper 1978). Three, 4-sided welded wire-panel cages (4 gauge, $10 \times 10 \mathrm{~cm}$ galvanized panels) enclosing $2.3 \mathrm{~m}^{2}$ were erected inside each enclosure and randomly located to protect forage from grazing during the grazing period. Two, $0.1858 \mathrm{~m}^{2}$ frames were located within each cage and all herbaceous vegetation was clipped at ground level and separated by species. Outside each cage, 2 additional $0.1858 \mathrm{~m}^{2}$ frames were clipped from previously selected areas that had similar cover and species composition to the caged plant community (Cook and Stubbendieck 1986, Pieper 1978). Cages were also erected in control plots and clipped following the grazing period. Vegetation samples were oven-dried and allowed to cool to room temperature before being weighed. Enclosures were not constructed to exclude wild ungulates (i.e. deer and elk). Pellet group counts (Eberhardt and Etten 1956, Neff 1968, Smallidge 1997, Treadway et al. 1998) were used to estimate the number of usedays plots received from wild ungulates.

\section{Cottonwood Populations}

Livestock use of cottonwoods was estimated by selecting 10 individual cottonwood saplings and labeling 10 twigs on each with a small colored wire, resulting in a total of 100 labeled twigs per plot. Individual twig lengths were measured in whole centimeters from the most terminal end of the twig to the lower part of the joint where the twig joins another stem (Hall and Max 1999). Twig measurements were recorded before and after grazing to determine an index of cottonwood utilization during the grazing period (Cook and Stubbendieck 1986). Grazing periods ranged between 2 and 8 days, so twig measurements were not greatly affected by growth during the grazing period.

Cottonwood sapling densities, mean sapling height, and mean number of twigs per sapling were estimated in each enclosure using $1 \mathrm{~m}$ wide belt transects that ran the entire length of the stream within each enclosure. All cottonwood saplings within 1 meter of the bank on each side of the stream were counted, and their heights, and number of twigs recorded. Cottonwood density, sapling height, and number of twigs per sapling were sampled once each year at the end of the growing season.

\section{Herbaceous Vegetation}

In addition to the 3 cages used to estimate grazing intensity, 4 cages were randomly located in each plot at the beginning of each growing season and used to estimate annual standing aboveground herbaceous phytomass. At the end of each year's growing season, $2,0.1858 \mathrm{~m}^{2}$ frames were located within each cage and all herbaceous vegetation was clipped to ground level and separated by species. Samples were oven-dried and allowed to cool to room temperature before being weighed.

Herbaceous species cover, richness, diversity, and evenness were estimated in each enclosure using the point-step linetransect method described by Evans and Love (1957). Twelve transects were systematically located within each plot. Twelve sampling points were recorded on each transect as they were paced each year at the end of the growing season.

Species richness was defined as the total number of species in a plot (Ludwig and Reynolds 1988). The inverse of Simpson's diversity index (Magurran 1988) was used to evaluate species diversity because it is more sensitive to changes in abundant species (Krebs 1989, Peet 1974), unlike Shannon's diversity index which is more sensitive to changes in rare species (Krebs 1989, Magurran 1988). Hill (1973) called the inverse of Simpson's diversity index N2. In this form, Simpson's diversity index can be most easily interpreted as the number of equally abundant species required to generate the observed diversity of the sample (Krebs 1989, Ludwig and Reynolds 1988).

Hill's E5 (Hill 1973) was selected to evaluate evenness rather than other commonly used evenness indices such as Pielou's J' (Pielou 1975) because E5 is not dependant on sample size or number of species in the sample (Ludwig and Reynolds 1988). Evenness expresses how species abundances are distributed among the various species (Magurran 1988). The parameter E5 approaches 0 as a single species becomes more dominant (Ludwig and Reynolds 1988). A community in which all species occur equally would have a greater evenness than a community with 1 or 2 dominant species (Green and Kauffman 1995).

\section{Analyses}

All analyses were conducted using SAS statistical programming package, version 8.2 (SAS 2001). To compensate for initial differences in cottonwood sapling abundance between each enclosure and to quantify the effects of 2 years of grazing treatments, analyses of cottonwood density, cottonwood height, and cottonwood twig number were based on comparisons of the numeric differences between initial readings for a variable (1999) and final readings (2001). Repeated measures analysis was used for analyses of herbaceous species cover, richness, diversity, evenness, and annual herbaceous phytomass. Analyses of cottonwood use was based on comparisons between pre-grazing and post-grazing twig length measurements.

Analyses of treatment effects were conducted with either 1-way or 2-way Analysis of Variance (ANOVA) using PROC MIXED (SAS 1996), depending on whether data were collected once a year at the end of the growing season, or before and after each period of grazing. One-way ANOVA was used to analyze data collected once each year at the end of each growing season such as cottonwood sapling density, sapling height, number of twigs per cottonwood sapling, herbaceous species cover, richness, diversity, and evenness. In 1-way analyses, grazing intensity treatments (light and moderate) were combined with season of use treatments (cool, warm, and dormant) in all possible combinations and augmented with the ungrazed control. Main effects of season of use and grazing intensity were tested using multiple degree of freedom contrast statements. If multiple degree of freedom tests were significant, single degree of freedom tests were examined. 
Two-way ANOVA was used to analyze data collected before and after each grazing period. Normality of all response variables was checked using PROC UNIVARIATE (SAS 1996). Differences between initial and final measurements were found to be normally distributed with the Shapiro-Wilk test for normality (Zar 1999). Significant differences among means in the ANOVA tests were identified using the protected least significant difference (LSD) method (Zar 1999). Results on all variables were considered significant if P-values were less than or equal to 0.05 .

\section{Results}

\section{Grazing Intensity}

On average, target grazing intensity levels were met during the 2-year study. Mean grazing intensity in the moderately grazed plots (target: $40-50 \%$ use of available standing forage) was $42 \%$ which was significantly greater $(P=0.0132)$ than the mean grazing intensity of $26 \%$ observed in the lightly grazed plots (target: 20-30\% use of available standing forage). Mean observed grazing intensity in the ungrazed plots was $0.2 \%$, which was significantly lower than grazing intensities in both the moderately and lightly grazed plots $(\mathrm{P}<$ $0.0001, P=0.0006$ respectively). Light, moderate, and no grazing intensity treatments were not significantly different among seasons $(P=0.1685)$, but were significant from each other within each grazing season $(\mathrm{P}<0.0001)$. Use occurring in the ungrazed plots was attributed to wild ungulates such as deer, elk or other wildlife. Seven elk use-days were estimated in ungrazed plots (Table 1).

\section{Cottonwoods}

Cottonwood use had a significant interaction $(\mathrm{P}=0.0079)$ between grazing intensity treatments and season of use treatments. There was an interaction because cottonwoods in moderately grazed and ungrazed enclosures received the most use

Table 1. Estimated number of use-days by wild ungulates in the Black Range of western New Mexico.

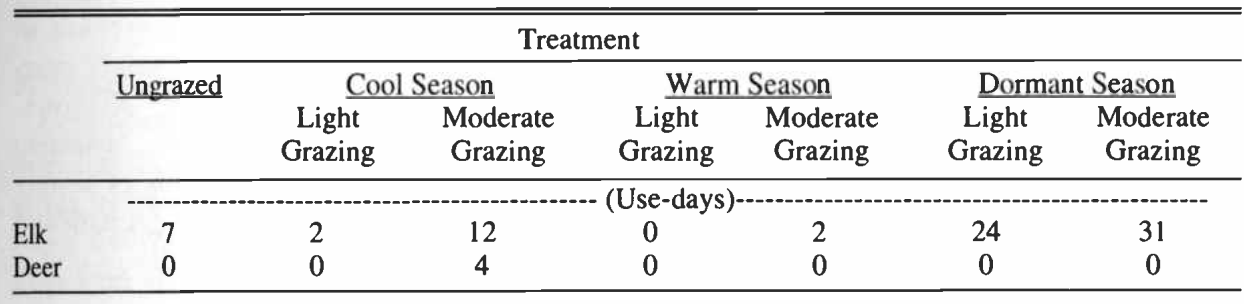

during the dormant season, whereas cottonwoods in lightly grazed enclosures received the most use during the cool season (Table 2). Main treatment effects were examined because mean cottonwood use in lightly grazed enclosures during the cool season was not significantly different from mean cottonwood use in lightly grazed enclosures grazed during the dormant season $(P=0.3063)$.

Both main treatment effects were significant. Grazing intensity had a significant effect $(P<0.0001)$ on cottonwood sapling use, as did season of grazing $(P=0.0062)$. Cottonwood saplings within the moderately grazed treatments experienced significantly greater use than the lightly grazed plots $(P=0.0027)$ and the ungrazed plots $(\mathrm{P}<0.0001)$. Cottonwood use was greatest during the dormant season which was significantly greater $(P=0.0017)$ than observed use during the warm season. Cottonwood sapling use during the cool season was not significantly different from cottonwood use during the dormant season $(P=0.0810)$ or cottonwood use during the warm season $(P=0.0819)$.

Cottonwood densities after 2 years of grazing were not significantly different from those initially estimated prior to the beginning of the study (Table 3). Neither grazing intensity nor season of use had a significant effect $(P=0.2363, P=0.9681$ respectively) on the differences in cottonwood densities from 1999 to 2001 . Although mean sapling height increased in all grazed plots, and decreased in the ungrazed plots (Table 3), these differences were not significantly different from each other as a result of grazing intensity $(P=$
Table 2. Use of cottonwood saplings as a result of grazing intensity (moderate: $\mathbf{4 0 - 5 0 \%}$ use, light: 20-30\% use, control: $0 \%$ use) and season of grazing treatments (warm: Aug-Sept, cool: May-June, dormant: Feb-Mar) in 2000 and 2001 in the Black Range of western New Mexico.

\begin{tabular}{llcc}
\hline \hline & \multicolumn{3}{c}{ Grazing Intensity } \\
\cline { 2 - 4 } Season of Use & $\begin{array}{c}\text { No Grazing } \\
\text { mean (SE) }\end{array}$ & $\begin{array}{c}\text { Light Grazing } \\
\text { mean (SE) }\end{array}$ & $\begin{array}{c}\text { Moderate Grazing } \\
\text { mean (SE) }\end{array}$ \\
\hline Cool Season & $0 \%(2 \%) \mathrm{D}^{*}$ & $25 \%(2 \%) \mathrm{BC}$ & $30 \%(2 \%) \mathrm{B}$ \\
Warm Season & $0 \%(1 \%) \mathrm{D}$ & $12 \%(1 \%) \mathrm{C}$ & $15 \%(1 \%) \mathrm{BC}$ \\
Dormant Season & $1 \%(1 \%) \mathrm{D}$ & $17 \%(2 \%) \mathrm{BC}$ & $54 \%(2 \%) \mathrm{A}$ \\
\hline
\end{tabular}

*Treatment means sharing the same letter were not significantly different at $\alpha=0.05$.

$0.0704)$. Season of use did not have a significant effect on mean sapling height $(\mathrm{P}=$ 0.4121 , Table 3). Number of twigs per sapling also did not appear to be significantly affected by either grazing intensity $(P=0.8004)$ or season of use $(P=0.3228$, Table 3).

\section{Herbaceous Vegetation}

Although grazing intensity did not have a significant effect on species richness ( $P$ $=0.3507$ ), season of grazing did create significant differences $(P=0.0114)$ during the 2 year study (Table 4). Species richness was not significantly different prior to the application of grazing intensity or season of grazing treatments $(P=0.3541$, $\mathrm{P}=0.1802$ respectively). Plots grazed in the cool season had significantly greater species richness than plots grazed in the warm or dormant seasons $(P=0.0141, P=$ 0.0051 respectively) (Table 4). Simpson's index was not significantly impacted by grazing intensity $(P=0.3556)$, but was significantly different by season of grazing $(P=0.0006)$ (Table 4). Plots grazed in the cool season had a significantly greater diversity index than those grazed in the warm or dormant seasons $(P=0.0017$, 0.0002 respectively) (Table 4 ). Plots grazed in the warm season also had a significantly greater diversity index than those grazed in the dormant season $(\mathrm{P}=$ 0.0427 ) (Table 4). Evenness was not significantly affected by season of use or grazing intensity $(\mathrm{P}=0.1205, \mathrm{P}=0.0823$ respectively) (Table 4).

Total annual phytomass of all herbaceous species was not significantly different as a result of grazing intensity or season of grazing treatments $(\mathrm{P}=0.7612, \mathrm{P}=$ 0.7245 respectively) (Table 5). Grazing intensity had a significant effect $(P=$ 0.0272 ) on graminoid cover. Ungrazed plots had significantly greater graminoid cover than lightly grazed plots $(\mathrm{P}=$ 0.0082 ) (Table 5). Graminoid cover in ungrazed plots versus moderately grazed plots was not significantly different $(\mathrm{P}=$ 0.0562 ), neither was graminoid cover in lightly grazed plots significantly different 
Table 3. Differences in cottonwood sapling density, height, and number of twigs per sapling from 1999 to 2001 in response to grazing intensity (moderate: $40-50 \%$ use, light: $20-30 \%$ use, control: $0 \%$ use) and season of grazing treatments (warm: Aug-Sept, cool: May-June, dormant: Feb-Mar) in the Black Range of western New Mexico.

\begin{tabular}{lccc}
\hline \hline & \multicolumn{3}{c}{ Grazing Intensity } \\
\cline { 2 - 4 } Variable & $\begin{array}{c}\text { No Grazing } \\
\text { mean (SE) }\end{array}$ & $\begin{array}{c}\text { Light Grazing } \\
\text { mean (SE) }\end{array}$ & $\begin{array}{c}\text { Moderate Grazing } \\
\text { mean (SE) }\end{array}$ \\
\hline Density (\# m ${ }^{-2}$ ) & $0.34(0.33) \mathrm{A}^{*}$ & $0.11(0.08) \mathrm{A}$ & $0.06(0.07) \mathrm{A}$ \\
Height $(\mathrm{cm})$ & $-9.7(2.7) \mathrm{A} \dagger$ & $3.4(4.9) \mathrm{AB}$ & $8.3(2.7) \mathrm{B} \dagger$ \\
Twigs / sapling & $1.8(2.8) \mathrm{A}$ & $2.8(2.1) \mathrm{A}$ & $3.6(0.9) \mathrm{A} \dagger$ \\
\hline & \multicolumn{4}{c}{ Season of Use } \\
\cline { 2 - 4 } & Cool Season & Warm Season & Dormant Season \\
Season of Use & mean (SE) & mean (SE) & mean (SE) \\
\hline Density (\# m $\left.{ }^{-2}\right)$ & $0.07(0.09) \mathrm{A}$ & $0.10(0.08) \mathrm{A}$ & $0.09(0.12) \mathrm{A}$ \\
Height $(\mathrm{cm})$ & $1.5(7.3) \mathrm{A}$ & $7.1(3.5) \mathrm{A} \ddagger$ & $8.8(3.0) \mathrm{A} \dagger$ \\
Twigs / sapling & $1.0(2.5) \mathrm{A}$ & $4.8(1.1) \mathrm{A} \dagger$ & $3.8(1.7) \mathrm{A} \ddagger$ \\
\hline
\end{tabular}

*Treatment means sharing the same uppercase letter within a row were not significantly different between grazing treatments at $\alpha=0.05$.

$\dagger$ Denotes cell value is significantly different than 0 at $\alpha=0.05$

$\ddagger$ Denotes cell value is significantly different than 0 at $\alpha=0.10$. in moderately grazed plots $(\mathrm{P}=0.2367)$ (Table 5). Significantly less bare ground was observed in the ungrazed plots than in the lightly or moderately grazed plots $(\mathrm{P}=$ $0.0500, \mathrm{P}=0.0047$ respectively) (Table $5)$. Litter cover was not significantly impacted by grazing intensity or season of use $(P=0.9742, P=0.9930$ respectively) (Table 5).

\section{Discussion}

\section{Cottonwood Responses}

Data collected in this study did not indicate that cattle grazing at light and moderate levels in the cool, warm, and dormant seasons significantly impacted woody riparian vegetation in these areas over the duration of the study period. Cottonwood saplings in moderately grazed plots received the greatest grazing pressure, especially those saplings in plots moderately grazed during the dormant season. Regardless of grazing pressure, cottonwood populations continued to grow or were not significantly different from initial conditions prior to the commencement of the study. Cottonwood densities were not significantly different from original estimates made prior to the beginning of grazing treatments. Mean height of cottonwood saplings increased in all grazed plots and decreased in the ungrazed plots. Number of twigs per sapling increased under all grazing regimes. These responses suggest that cottonwood populations in the Black Range of western New Mexico will thrive and continue to serve the ecological functions they perform under the intensities of grazing and seasons of use employed in this study.
Table 4. Species richness, diversity, and evenness response to grazing intensity (moderate: 40-50\% use, light: $20-30 \%$ use, control: $0 \%$ use) and seasons of grazing treatments (warm: Aug-Sept, cool: May-June, dormant: Feb-Mar) in the Black Range of western New Mexico.

\begin{tabular}{lccc}
\hline \hline & \multicolumn{3}{c}{ Grazing Intensity } \\
\cline { 2 - 4 } Variable & No Grazing & Light Grazing & $\begin{array}{c}\text { Moderate Grazing } \\
\text { mean (SE) }\end{array}$ \\
\hline Species Richness & $24(2.6) \mathrm{A}^{*}$ & $23(1.6) \mathrm{A}$ & $22(1.1) \mathrm{A}$ \\
Simpson's Index (N2) & $9.96(0.92) \mathrm{A}$ & $10.27(1.05) \mathrm{A}$ & $9.86(0.71) \mathrm{A}$ \\
Evenness (E5) & $0.665(0.033) \mathrm{A}$ & $0.731(0.029) \mathrm{A}$ & $0.746(0.018) \mathrm{A}$ \\
\hline & \multicolumn{4}{c}{ Season of Use } \\
\cline { 2 - 4 } & Cool Season & Warm Season & Dormant Season \\
Variable & mean (SE) & mean (SE) & mean (SE) \\
\hline Species Richness & $25.9(1.6) \mathrm{A}$ & $21.0(1.4) \mathrm{B}$ & $19.8(1.0) \mathrm{B}$ \\
Simpson's Index (N2) & $12.45(1.05) \mathrm{A}$ & $9.56(0.98) \mathrm{B}$ & $8.18(0.63) \mathrm{C}$ \\
Evenness (E5) & $0.766(0.022) \mathrm{A}$ & $0.744(0.038) \mathrm{A}$ & $0.704(0.024) \mathrm{A}$ \\
\hline
\end{tabular}

*Treatment means sharing the same uppercase letter within a row were not significantly different between grazing treatments at $\alpha=0.05$.
Why there was a decline in cottonwood sapling height in ungrazed enclosures in this study is unknown. Many of the saplings in the enclosures appeared to be vegetative sprouts from existing mature trees and may not grow to maturity unless the health of the parent tree severely declines as a result of death, harvest, or disease (Kinch 1989). We did not quantify the proportion of vegetative sprouts in our study area because we did not want to destructively sample our populations. Observed height declines in ungrazed enclosures may have been the result of a natural senescence cycle of vegetative sprouts or some other factor such as water stress or lack of disturbance. Differential survival rates of cottonwood vegetative sprouts versus individual seedlings are not well understood and merit further examination.

Alternatively, the observed decline of cottonwood sapling height in ungrazed enclosures could have been caused by a lack of disturbance. Cottonwoods are adapted to a high disturbance environments (Braatne et al. 1996). Without disturbance, saplings may naturally senesce. In addition to periodic flooding or other disturbance, livestock grazing may elicit a compensatory growth response (McNaughton 1983, Peinetti et al. 2001, Zvereva and Kozlov 2001) from cottonwood saplings. As cottonwood saplings are grazed, the number of axillary meristems is reduced and the abili. ty for new tissue growth may be constrained (Peinetti et al. 2001). Cottonwood saplings in this study seemed to overcome this constraint by producing more twigs (Table 3 ) from surviving axillary meristems as well as from lateral meristems on older twigs (Zvereva and Kozlov 2001). Similar responses to browsing have been documented in other woody species (Danell et al.. 1994, du Toit et al. 1990, Peinetti et al. 2001, Zvereva and Kozlov 2001). In ungrazed enclosures, disturbances from grazing were absent. It was possible that wild ungulates could have provided similar grazing disturbances, but their presence was not very great in ungrazed enclosures (Table 1).

Results of other studies examining effects of livestock grazing on woody riparian vegetation have yielded mixed results (Brown and McDonald 1995, Pieper 1994). Carothers (1977) and Glinski (1977) observed decreases in riparian shrub densities as a result of grazing pressure in southern Arizona. Phytomass, height, crown area, mainstem diameter, and number of stems of woody riparian species all increased dramatically following the removal of cattle in north. 
Table 5. Total annual standing phytomass and cover responses to grazing intensity (moderate: 40-50\% use, light: $20-30 \%$ use, control: $0 \%$ use) and seasons of grazing treatments (warm: Aug-Sept, cool: May-June, dormant: Feb-Mar) in the Black Range of western New Mexico.

\begin{tabular}{|c|c|c|c|}
\hline \multirow[b]{2}{*}{ Variable } & \multicolumn{3}{|c|}{ Grazing Intensity } \\
\hline & $\begin{array}{l}\text { No Grazing } \\
\text { mean (SE) }\end{array}$ & $\begin{array}{l}\text { Light Grazing } \\
\text { mean (SE) }\end{array}$ & $\begin{array}{c}\text { Moderate Grazing } \\
\text { mean (SE) }\end{array}$ \\
\hline$\overline{\text { Phytomass }\left(\mathrm{kg} \mathrm{ha}^{-1}\right)}$ & $1,241(156) A^{*}$ & $1,183(83) \mathrm{A}$ & $1,088(88) \mathrm{A}$ \\
\hline Graminoid Cover (\%) & $52(2) \mathrm{A}$ & 44 (2) B & 47 (1) $A B$ \\
\hline Forb Cover (\%) & 21 (3) $\mathrm{A}$ & $26(2) \mathrm{A}$ & $22(2) \mathrm{A}$ \\
\hline Litter $(\%)$ & $22(4) \mathrm{A}$ & $22(2) \mathrm{A}$ & 22 (1) A \\
\hline \multirow[t]{3}{*}{ Bare Ground (\%) } & 4 (1) B & 8 (1) A & 9 (1) A \\
\hline & \multicolumn{3}{|c|}{ Season of Use } \\
\hline & $\begin{array}{c}\text { Cool Season } \\
\text { mean (SE) }\end{array}$ & $\begin{array}{l}\text { Warm Season } \\
\text { mean (SE) }\end{array}$ & $\begin{array}{l}\text { Dormant Season } \\
\text { mean (SE) }\end{array}$ \\
\hline Phytomass $\left(\mathrm{kg} \mathrm{ha}^{-1}\right)$ & $1,220(114) \mathrm{A}$ & $1,153(146) \mathrm{A}$ & $1,389(123) \mathrm{A}$ \\
\hline Graminoid Cover (\%) & 44 (3) A & $46(2) \mathrm{A}$ & 47 (2) A \\
\hline Forb Cover $(\%)$ & 27 (3) A & $22(3) \mathrm{A}$ & 23 (3) A \\
\hline Litter $(\%)$ & $23(2) \mathrm{A}$ & 23 (2) A & 20 (2) A \\
\hline Bare Ground (\%) & 7 (1) A & 9 (1) A & 9 (2) A \\
\hline
\end{tabular}

${ }^{*}$ Treatment means sharing the same uppercase letter within a row were not significantly different between grazing treatments at $\alpha=0.05$.

eastern Oregon (Case and Kauffman 1997). Woody riparian species density and cover increased following the cessation of cattle grazing in north central Colorado (Schultz and Leininger 1990). Light grazing pressure was observed on riparian shrub communities over 3 years in northeastern Oregon, but shrub communities were not negatively impacted (Kauffman et al. 1983b). Shrub densities and mean heights were found to be significantly greater in exclosures, and remained unchanged in grazed areas (Kauffman et al. 1983b). Another study found woody riparian species densities and mean heights continued to increase regardless of different levels of applied grazing intensities in central Idaho (Clary 1999). Such disparate results between similar studies are not surprising (Green and Kauffman 1995). Each riparian system is unique (Kauffman et al. 1996, Skovlin 1984) and in a different state of equilibrium (Stringham et al. 2001, Westoby et al. 1989). Therefore, each different riparian area responds differently to similar disturbances (Clark 1998, Clary 1995). Both negative and positive results from livestock grazing are possible (Brown and McDonald 1995, Carothers 1977, Case and Kauffman 1997, Clary 1999, Glinski 1977, Kauffman et al. 1983b, Schultz and Leininger 1990).

\section{Herbaceous Vegetation}

Graminoid cover in ungrazed enclosures was significantly greater than graminoid cover in lightly grazed enclosures. Unlike other studies (Green and Kauffman 1995, Popolizio et al. 1994, Smith and Rushton
1994), we did not find species richness to be lowest in the ungrazed enclosures. Following the cessation of grazing, it has been observed that a few aggressive species out-compete less aggressive herbaceous species for limited resources (Green and Kauffman 1995, Smith and Rushton 1994, USDA and NRCS 1997). This often petitive species and decreased species richness for that area (Younger 1972). Stable herbaceous communities are often maintained by livestock controlling the aggressive species through grazing or trampling (Smith and Rushton 1994). When grazing is removed, changes may occur in the herbaceous community until a new equilibrium is reached (Westoby et al. 1989). In this study, grazing disturbances prior to the cessation of grazing may not have been substantial enough to cause an equilibrium adjustment following the removal of grazing or alternatively, not enough time had elapsed after the cessation of grazing to allow for the potential changes to occur.

Species richness and Simpson's diversity index were significantly greater in plots grazed in the cool season. Additional species not previously found in plots grazed during the cool season but found in include Lambert's locoweed (Oxytropis lambertii Pursh), squirreltail (Elymus elymoides [Raf.] Swezey), edible valerian (Valeriana edulis Nutt. Ex T. and G.), and showy golden eye (Viguiera multiflora Nutt.) (data not shown). These species are present in both watersheds outside our grazing enclosures and propagules may have been spread as a direct consequence results in the extinction of the less-com3 out of the 4 plots after 2 years of grazing of grazing (i.e. seed was transported by cattle into the enclosures) or as an indirect consequence of grazing. May and June, when cool season grazing was conducted, is typically the driest time of year in this area. The stress resulting from cattle grazing in the cool season may have opened up ecological niches, facilitated establishment of new species (Green and Kauffman 1995, Popolizio et al. 1994), and contributed to the proliferation of species already existing in the immediate vicinity of the enclosures (Holechek et al. 1998, Kauffman et al. 1983b).

Similar to woody riparian vegetation, other work has shown livestock grazing also has inconsistent effects on herbaceous riparian plant communities (Clary 1999, Clary and Medin 1990, Green and Kauffman 1995, Smith and Rushton 1994). In one study at Sheep Creek, Colo. (Lamman 1994), as much as $90 \%$ of the aboveground plant material of a Nebraska sedge (Carex nebraskensis Dewey) community was removed for 3 years in a row and no significant changes in total nonstructural carbohydrates were observed relative to unclipped control plots. In Oregon, herbaceous species composition in ungrazed areas shifted after 3 years of no grazing to include more mesic and hydric species while grazed areas remained relatively unchanged (Kauffman et al. 1983b). Clary (1999) found little change in graminoid canopy cover between lightly, moderately, and ungrazed areas. Kauffman et al. (1983b) concluded that areas having greater standing phytomass prior to the cessation of grazing experience a greater response following the discontinuation of grazing. Livestock grazing disturbances do not always elicit the same responses in herbaceous species because each riparian area is a unique system (Kauffman et al. 1996, Skovlin 1984). Grazing intensity, season of use, excreta deposited, and even residual saliva have the potential to influence the productivity and botanical composition of a riparian community (Heitschmidt 1990, Matches 1992), but results are largely a reflection of the individuality of each riparian area (Clary 1995, Green and Kauffman 1995).

\section{Conclusions}

Riparian ecosystems are important ecological and economic resources in the arid and semi-arid American West (Fleischner 1994). When conducted properly, livestock grazing can be compatible with riparian systems, provided the mainte- 
nance of their ecological functions are included as management objectives and the integrity of the riparian ecosystem is kept intact (Platts and Nelson 1985). We did not find cattle grazing to have negative impacts on the 2 streams studied when grazed at light or moderate intensities in cool, warm, or dormant seasons. Cottonwood densities remained unchanged under all grazing regimes. Cottonwood heights increased in all grazed plots and decreased in ungrazed plots. Mean number of twigs per sapling increased in all treatments. Herbaceous species richness and diversity were not affected by grazing intensity, although they were significantly greater in enclosures grazed during the cool season.

Recommending blanket management applications (Bryant 1985, Clary and Webster 1989) for all riparian areas ignores their inherent complexity and individuality (Clary 1999, Green and Kauffman 1995). Virtually all riparian areas respond differently to similar disturbances (Clary 1995). This was a shortterm study and changes in community structure may become more apparent over longer periods. No single riparian area management approach is best in all situations (Clary 1999, Green and Kauffman 1995) but the grazing systems used in this study appear to have been successful at maintaining riparian plant communities and the functions they serve.

\section{Literature Cited}

Armour, C., D. Duff, and W. Elmore. 1994. The effects of livestock grazing on western riparian and stream ecosystem. Fisheries 19:9-12.

Baker, T. T. and J. C. Boren. 2000. Livestock management in southwestern riparian areas dominated by woody vegetation: A summary and extrapolation of the literature. Range Improvement Task Force, Agr. Exp. Sta., Coop. Exten. Serv., New Mexico State Univ. Report 50. Las Cruces, N.M.

Behnke, R. J. 1979. Values and protection of riparian ecosystems, p. 164-167. In: G.A. Swanson (ed.), Gen. Tech. Rep. RM-65. U.S. Dep. of Agr., Forest Serv., Rocky Mountain Forest and Range Exp. Station, Fort Collins, Colo.

Belsky, A. J. and D. M. Blumenthal. 1997. Effects of livestock Grazing on stand dynamics and soil in upland forests of the interior west. Conserv. Biol. 11: 315-327.

Belsky, A. J., A. Matzke, and S. Uselman. 1999. Survey of livestock influences on stream and riparian ecosystems in the Western United States. J. Soil and Water Conserv. 54: 419-431.
Braatne, J. H., S. B. Rood, and P. E. Heilman. 1996. Life history, ecology, and conservation riparian cottonwoods in North America. Chapter 3, p. 57-85. In: R.F. Stettler, H.D. Bradshaw, Jr., P.E. Heilman, T.M. Hinckley (ed.) Biology of Populus and its implications for management and conservation. National Research Council of Canada Research Press, Ottawa, Ont., Canada.

Bradley, C. E. and D. G. Smith. 1986. Plains cottonwood recruitment and survival on a prairie meandering river floodplain, Milk River, southern Alberta and northern Montana. Can. J. Bot. 64:1433-1442.

Brown, J. H. and W. McDonald. 1995. Livestock grazing and conservation on southwestern rangelands. Conserv. Biol. 9:1644-1647.

Bryant, L. D. 1985. Livestock management in the riparian ecosystem, p. 285-289. In: R.R. Johnson, C.D. Ziebell, D.R. Patton, P.F. Ffolliott, R.H. Hamre (ed.) Riparian Ecosystems and Their Management: Reconciling Conflicting Uses. Gen. Tech. Rep. RM-120. U.S. Dep. of Agr., Forest Service, Fort Collins, Colo.

Busch, D. E. and S. D. Smith. 1995. Mechanisms associated with decline of woody species in riparian ecosystems of the southwestern U.S. Ecol. Monogr. 65:347-370.

Carothers, S. W. 1977. Importance, preservation, and management of riparian habitats: an overview. In: R.R. Johnson, D.A. Jones (ed.) Importance, Preservation, and Management of Riparian Habitats. Gen. Tech. Rep. RM43. U.S. Dep. of Agr., Forest Service, Rocky Mountain Forest and Range Exp. Station, Fort Collins, Colo.

Case, R. L. and J. B. Kauffman. 1997. Wild ungulate influences on the recovery of willows, Black Cottonwood and Thin-leaf Alder following cessation of cattle grazing in northeastern Oregon. Northwest. Sci.71:115-126.

Clark, E. A. 1998. Landscape variables affecting livestock impacts on water quality in the humid temperate zone. Can. J. Plant Sci. 78: 181-190.

Clary, W. P. 1995. Vegetation and soil responses to grazing simulation of riparian meadows. J. Range Manage. 48:18-25.

Clary, W. P. 1999. Stream channel and vegetation responses to late spring grazing. J. Range Manage. 52:218-227.

Clary, W. P. and D. E. Medin. 1990. Differences in vegetation biomass and structure due to cattle grazing in a northern Nevada riparian ecosystem. Gen. Tech. Rep. INT-427. U.S. Dep. of Agr., Forest Service. Ogden, Ut.

Clary, W. P. and B. F. Webster. 1989. Managing grazing of riparian areas in the intermountain region. Gen. Tech. Rep. INT263. U.S. Dep. of Agr., Forest Service. Ogden, Ut.

Clifton, C. 1989. Effects of vegetation and land use on channel morphology, p. 121-129. In: R.E. Greenwell, B.A. Barton, J.L. Kershener (ed.) Practical Approaches to Riparian Resource Management. U.S.
Bureau of Land Management, Billings Montana, U.S. Government Printing Office, Washington, D.C.

Cook, C. W. and J. Stubbendieck. 1986. Range Research: Basic problems and techniques. Soc. for Range Manage., Denver, Colo.

Danell, K., R. Bergstrom, and L. Edenius. 1994. Effects of large mammalian browsers on architecture, biomass, and nutrients of woody plants. J. Mammalogy 75:833-844.

Davis, G. A. 1977. Management alternatives for the riparian habitat in the Southwest, $p$. 59-67. In: R.R. Johnson, D.A. Jones (ed.) Importance, preservation and management of riparian habitat: A symposium. Gen. Tech. Rep. RM-43. U.S. Dep. of Agr., Forest Service, Rocky Mountain Forest and Range Exp. Sta., Fort Collins, Colo.

DeBano, L. F. and L. J. Schmidt. 1989. Improving southwestern riparian areas through watershed management. In: General Techni. Report RM-182. U.S. Dep. of Agr., Forest Service, Rocky Mountain Forest and Range Exp. Sta., Fort Collins, Colo.

Donahue, D. L. 1999. Western Range Revisited: removing livestock from public lands to conserve native biodiversity. Univ. of Oklahoma Press, Norman, Okla.

du Toit, J. T., J. P. Bryant, and K. Frisby. 1990. Regrowth and palatability of Acacia shoots following pruning by African savanna browsers. Ecol. 71:149-154.

Eberhardt, L. and R. C. V. Etten. 1956. Evaluation of the pellet group count as a deer census method. J. Wildl. Manage. 20: 70-74.

Ellis, L. M., C. S. Crawford, and J. Manuel C. Molles. 1998. Comparison of litter dynamics in native and exotic riparian vegetation along the middle Rio Grande of central New Mexico. J. Arid Environ. 38:283-296.

Elmore, W. and R. L. Beschta. 1987. Riparian areas: perceptions in management Rangelands 9:260-265.

Elmore, W. and B. Kauffman. 1994. Riparian and watershed systems: degradation and restoration, p. 212-231. In: M. Vavra, W.A Laycock, R.D. Pieper (ed.) Ecological Implications of Livestock Herbivory in the West. Soc. for Range Manage., Denver, Colo.

Evans, R. A. and R. M. Love. 1957. The steppoint method of sampling - a practical tool in range research. J. Range Manage. 10:208-213.

Fleischner, T. L. 1994. Ecological costs of livestock grazing in Western North America. Conserv. Biol. 8:629-644.

Gee, G. W. and J. W. Bauder. 1986. Particlesize analysis, p. 383-411. In: A. Klute (ed. Methods of Soil Analysis. $2^{\text {nd }}$ ed. American Society of Agronomy, Madison, Wis.

Glinski, R. L. 1977. Regeneration and distribution of Sycamore and Cottonwood trees along Sonoita Creek, Santa Cruz County, Arizona, p. 116-123. In: R.R. Johnson, D.A. Jones (ed.) Importance, preservation and management of riparian habitat: A sympo. sium. Gen. Tech. Rep. RM-43. U.S. Dep. of Agr., Forest Service, Rocky Mountain Forest 
and Range Exp. Sta., p. 116-123, Fort Collins, Colo.

Goodwin, C. N., C. P. Hawkins, and J. L. Kershner. 1997. Riparian restoration in the western United States: Overview and perspective. Restoration Ecol. 5: 4-14.

Green, D. M. and J. B. Kauffman. 1995. Succession and livestock grazing in a northeastern Oregon riparian ecosystem. J. Range Manage. 48:307--313.

Gunderson, D. R. 1968. Floodplain use related to stream morphology and fish populations. J. Wildl. Manage. 32:507-514.

Hall, F. C. and T. Max. 1999. Technical note: test of observer variability in measuring riparian shrub twig length. J. Range Manage. 52 633-636.

Heimann, D. C. and M. J. Roell. 2000. Sediment loads and accumulation in a small riparian wetland system in northern Missouri. Wetlands 20: 219-231.

Heitschmidt, R. K. 1990. The role of livestock and other herbivores in improving rangeland vegetation. Rangelands 12:112-115.

Hill, M. O. 1973. Diversity and evenness: a unifying notation and its consequences. Ecol. 54: $427-432$.

Holechek, J. L., R. D. Pieper, and C. H. Herbel. 1998. Range Management: Principles and Practices. Prentice Hall, Upper Saddle River, N.J.

Howe, W. H. and F. L. Knopf. 1991. On the imminent decline of Rio Grande cottonwoods in central New Mexico. The Southwestern Natur. 36:218-224.

Jones, J. A., F. J. Swanson, B. C. Wemple, and K. Snyder. 2000. Effects of roads on hydrology, geomorphology, and disturbance patches in stream networks. Conserv. Biol 14:76-85.

Kauffman, J. B. and W. C. Krueger. 1984. Livestock impacts on riparian ecosystems and streamside management implications. A review. J. Range Manage. 37:430-438.

Kauffman, J. B., W. C. Krueger, and M. Vavra. 1983a. Impacts of cattle on streambanks in northeastern Oregon. J. Range Manage. 36: 683-685.

Kauffman, J. B., W. C. Krueger, and M. Vavra. 1983b. Effects of late season cattle grazing on riparian plant communities. J. Range Manage. 36:685-691.

Kauffman, J. B., N. Otting, D. Lytjen, and R. L. Beschta. 1996. Ecological principles and approaches to riparian restoration in the western United States, p. 142-169. In: A Guide to the Restoration of Watersheds and Native Fish in the West. The Pacific Rivers Council, Inc., Corvallis, Ore.

Kinch, G. 1989. Riparian area management: grazing management in riparian areas. In: Gen. Tech. Rep. TR-1737-4. U.S. Dep. of the Interior, Bur. of Land Manage., p.44, Denver, Colo.

Kovalchik, B. L. and W. Elmore. 1992. Effects of cattle grazing systems on willowdominated plant associations in central Oregon, p. 111-119. In: Gen. Tech. Rep. INT-289. U.S. Dep. of Agr., Forest Service, Intermountain Forest and Range Exp. Sta., Ogden, Ut.
Krebs, C. J. 1989. Ecological Methodology. Harper and Row, New York, N.Y.

Lamman, J. S. 1994. Effects of Season and Intensity of Defoliation on Two Important Montane Riparian Species. M.S. Thesis. Colorado State University. Fort Collins, Colo. 119 p.

Larsen, R. E., W. C. Krueger, M. R. George, M. R. Barrington, J. C. Buckhouse, and D. E. Johnson. 1998. Viewpoint: livestock influences on riparian zones and fish habitat: literature classification. J. Range Manage. 51:661-664.

Li, H. W., G. A. Lamberti, T. N. Pearsons, C. K. Tait, J. Li, and J. C. Buckhouse. 1994. Cumulative effects of riparian disturbances along high desert trout streams of the John Day basin, Oregon. Trans. Amer. Fish. Soc. 123:627-640.

Ludwig, J. A. and J. F. Reynolds. 1988. Statistical Ecology: A Primer on Methods and Computing. Wiley and Sons, New York, N.Y.

Magilligan, F. J. and P. F. McDowell. 1997. Stream channel adjustments following elimination of cattle grazing. J. Amer. Water Res. Assoc. 33:867-878.

Magurran, A. E. 1988. Ecological Diversity and Its Measurement. Princeton Univ. Press, Princeton, N.J.

Martin, D. W. and J. C. Chambers. 2001. Restoring degraded riparian meadows: biomass and species responses. J. Range Manage. 54:284-291.

Matches, A. G. 1992. Plant response to grazing: a review. J. Prod. Agr. 5:1-7.

McNaughton, S. J. 1983. Compensatory plant growth as a response to herbivory. Oikos 40: 329-336.

Meehan, W. R. 1991. Introduction and Overview, p. 1-15. In: W.R. Meehan (ed.) Influences of Forest and Rangeland Management on Salmonid Fishes and Their Habitats. Amer. Fisheries Soc. Spec. Publ. 19, Bethesda, Md.

Meehan, W. R. and W. S. Platts. 1978. Livestock grazing and the environment. J. Soil and Water Conserv. 33:274-278.

Millar, R. G. 2000. Influence of bank vegetation on alluvial channel patterns. Water Resources Res. 36:1109-1118.

Murphy, M. L. and W. R. Meehan. 1991. Stream Ecosystems, p. 17-46. In: W.R. Meehan (ed.) Influences of Forest and Rangeland Management on Salmonid Fishes and Their Habitats. Amer. Fisheries Soc. Spec. Publ. 19, Bethesda, Md.

Naiman, R. J. 1988. Alteration of North American streams by beaver. BioSci. 38 : 753-762.

Neff, D. J. 1968. The pellet-group count technique for big game trend, census, and distribution: A review. J. Wildl. Manage. 32:597-614.

Pearce, R. A., M. J. Trlica, W. C. Leininger, D. E. Mergen, and G. W. Frasier. 1998. Sediment movement through riparian vegetation under simulated rainfall and overland flow. J. Range Manage. 51:301-308.
Peet, R. K. 1974. The measurement of species diversity. Annu. Rev. of Ecol. and Systematics 5:285-307.

Peinetti, H. R., R. S. C. Menezes, and M. B. Coughenour. 2001. Changes induced by elk browsing in the aboveground biomass production and distribution of willow (Salix monticola $\mathrm{Bebb}$ ): their relationships with plant water, carbon, and nitrogen dynamics. Oecologia 127:334-342.

Pielou, E. C. 1975. Ecological Diversity. Wiley-Interscience, New York, N.Y.

Pieper, R. D. 1978. Measurement Techniques for Herbaceous and Shrubby Vegetation. New Mexico State Univ., Las Cruces, N..M.

Pieper, R. D. 1994. Ecological implications of livestock grazing, p. 177-211: In: M. Vavra, W.A. Laycock, R.D. Pieper (ed.) Ecological Implications of Livestock Herbivory in the West. Soc. for Range Manage., Denver, Colo.

Platts, W. S. 1991. Livestock grazing, p. 389-423. In: W.R. Meehan (ed.) Influences of Forest and Rangeland Management on Salmonid Fishes and Their Habitats. Amer. Fish. Soc. Special Publ. 19, Bethesda, Md.

Platts, W. S. and R. L. Nelson. 1985. Streamside and upland vegetation use by cattle. Rangelands 7:5-7.

Popolizio, C. A., H. Goetz, and P. L. Chapman. 1994. Short-term response of riparian vegetation to 4 grazing treatments. J. Range Manage. 47:48-59.

Rhodes, B. J., C. B. Marlow, and H. W. Sherwood. 1995. Monitoring streambank stability: Grazing impacts or stream variability. Montana AgRes. 12:3-8.

Rinne, J. N. 1988. Grazing effects on stream habitat and fishes: Research design considerations. N. Amer. J. Fish. Manage. 8:240-247.

Rinne, J. N. 1999. Fish and grazing relationships. Fisheries Habitat 24:12-21.

Rood, S. B. and S. Heinze-Milne. 1989. Abrupt downstream forest decline following river damming in southern Alberta. Can. J. Bot. 67:1744-1749.

Rosgen, D. L. 1994. A classification of natural rivers. Catena 22:169-199.

SAS. 1996. SAS Programming Language. SAS Institute, Inc., Cary, N.C.

SAS. 2001. SAS Software. Version 8.2. SAS Institute, Inc., Cary, N.C.

Schultz, T. T. and W. C. Leininger. 1990. Differences in riparian vegetation structure between grazed areas and exclosures. J. Range Manage. 43:295-299.

Scurlock, D. 1998. From the Rio to the Sierra: An environmental history of the middle Rio Grande Basin. In: Rocky Mountain Research Station Gen. Tech. Rep. RMRS-GTR-5. U.S. Dep. of Agr., Forest Service, Fort Collins, Colo.

Sidle, R. C. and A. Sharma. 1996. Stream channel changes associated with mining and grazing in the Great Basin. J. Environ. Quality 25:1111-1121.

Skovlin, J. M. 1984. Impacts of grazing on wetlands and riparian habitat: a review of our knowledge, p. 1001-1103. In: Developing Strategies for Rangeland Management. Westview Press, Boulder, Colo. 
Smallidge, S. T. 1997. The Corona Range and Livestock Research Ranch Mule Deer Study. MS Thesis. New Mexico State Univ. Las Cruces, N..M.. $56 \mathrm{p}$.

Smith, R. S. and S. P. Rushton. 1994. The effects of grazing management on the vegetation of mestrophic (meadow) grassland in northern England. J. App. Ecol. 31:13-24.

Souders, C. E. and T. G. Subirge. 1984. Terrestrial Ecosystems Survey Report. Black Range and Mimbres Ranger Districts, Gila National Forest, New Mexico, Silver City, N..M..

Stringham, T. K., W. C. Krueger, and D. R. Thomas. 2001. Application of non-equilibrium ecology to rangeland riparian zones. J. Range Manage. 54:210-217.

Stromberg, J. C. and D. T. Patten. 1992. Mortality and age of black cottonwood stands along diverted and underdiverted streams in the eastern Sierra Nevada, California. Madrono 39:205-223.
Swanson, S. 1989. Priorities for riparian management. Rangelands 11:228-230.

Todd, M. and W. Elmore. 1997. Historical changes in western riparian ecosystems, $p$. 454-468. In: Transactions of the $62^{\text {nd }}$ North Amer. Wildl. and Natural Resources Conf., Washington, D.C.

Treadway, M., V. W. Howard, C. Allison, M. K. Wood, and J. Boren. 1998. Forage utilization by elk and livestock in selected riparian areas in the Gila National Forest. In: Report 47. Range Improvement Task Force, Agri. Exp. Stat., Coop. Exten. Service, New Mexico State Univ., Las Cruces, N..M.

Trimble, S. W. and A. C. Mendel. 1995. The cow as a geomorphic agent - A critical review. Geomorphology 13:233-253.

USDA and NRCS. 1997. National Range and Pasture Handbook. U.S. Government Printing Office, Washington, D.C.
Weaver, W. and D. Hagans. 1996. Sediment treatments and road restoration: protecting and restoring watersheds from sedimentrelated impacts, p. 109-215. In: Healing the Watershed: A Guide to the Restoration of Watersheds and Native Fish in the West. The Pacific Rivers Council, Inc., Corvalis, Ore.

Westoby, M., B. Walker, and I. Noy-Meir. 1989. Opportunistic management for rangelands not at equilibrium. J. Range Manage. 42:266-274.

Younger, V. B. 1972. Physiology of defoliation and regrowth, p. 292-303. In: V.B. Younger, C.M. McKell (ed.) The Biology and Utilization of Grasses. Academic Press, New York, N.Y.

Zar, J. H. 1999. Biostatistical Analysis. Prentice-Hall, Upper Saddle River, N..J.

Zvereva, E. L. and M. V. Kozlov. 2001. Effects of pollution-induced habitat disturbance on the response of willows to simulated herbivory. Ecol. 89:21-30. 